\title{
Analysis of Factors Affecting The Demand of Broiler Chicken Meat In Binjai City
}

\author{
Ummi Hasanah Nasution, Edhy Mirwandhono*, Ma'ruf Tafsin, Hasnudi, and Armyn Hakim \\ Daulay
}

Animal Production Study Program, Faculty of Agriculture, Universitas Sumatera Utara, Medan 20155, Indonesia

*Email: radikalbebas3003@yahoo.co.id

\begin{abstract}
Consumption of broiler chicken meat increase year by year in line with public awareness increased of animal products. The purpose of this research was identify the factor of family's dependent number $\left(\mathrm{X}_{1}\right)$, educational level $\left(\mathrm{X}_{2}\right)$, family income $\left(\mathrm{X}_{3}\right)$, price of broiler chicken $\left(\mathrm{X}_{4}\right)$, taste $\left(\mathrm{X}_{5}\right)$, age of respondent $\left(\mathrm{X}_{6}\right)$, and price of substitution was egg $\left(\mathrm{X}_{7}\right)$. The analysis method used in this research was multiple linear regression analysis method by using SPSS 22.0. Sampling technique with slovin method with the samples were100 consumers of broiler chicken meat. This research was conducted from October until November 2017.

The results showed that value of determination $\left(\mathrm{R}^{2}\right)$ was 0,704 . Simultaneously, the variables showed a significant effect $(\mathrm{P}<0,05)$ to the demand of broiler chicken meat. Partially, family's dependent number, income, chicken meat's prices and tastes had a significant effect to the demand of broiler chickens while the educational level, age of respondents and the price of egg did not give significant effect on the demand of broiler chicken meat in Binjai City. The conclusion of this research showed that the taste was the most significant variable to the demand of broiler chicken and then followed by the family's dependent number, price of broiler chicken meat and family income.
\end{abstract}

Keywords: demand, broiler chicken, price, binjai city

Received 12 May 2019 | Revised 12 June 2019 | Accepted 1 August 2019

\section{Introduction}

Broiler chicken consumption continues to increase every year and is the most rapidly increasing commodity compared to other meat commodities. Meat is one source of animal protein with relatively affordable prices, easy to obtain and easy to process. Meeting the needs of animal 
origin is very important for the body because it is related to the problem of fulfilling nutrition in supporting the development of population growth.

The increase in chicken meat consumption in Indonesia is caused by the increase in people's income, improvement in education levels, and increased public awareness of the need for nutritional intake. The government in its efforts to spur an increase in chicken meat consumption issued a target of consumption of chicken carcass meat in 2015 of $10.5 \mathrm{~kg}$ per capita / year and in 2018 it is projected to reach $15.15 \mathrm{~kg}$ per capita / year.

Similarly, the demand for chicken meat in the city of Binjai has increased fluctuating, affecting the amount of chicken meat production in Binjai City. The number of broiler production in the City of Binjai in 2011 was 108,470 and in 2012 it increased 53\%, namely 203,570, in 2013 172,780 and in 2014 184,730, while in 2015 there was an increase of 10\% to 206,440. From these data it can be estimated that there are a number of factors that influence the increase in demand for chicken meat.

The purpose of this research was to identify the factors of the number of dependents, level of education, family income, price of broiler meat, tastes, age of respondents, and prices of substitute items, namely eggs on demand for broiler chicken in Binjai City.

\section{Methods}

\subsection{Time and Place of Study}

This research was conducted in three traditional markets in the Municipality of Binjai. This research was conducted in October - November 2017.

\subsection{Sampling Method}

The sample in this study is consumers of broiler chicken meat. The method of determining consumer respondents is done by the searchental sampling), which is the retrieval of respondents from consumers who are shopping for broiler meat that is most easily obtained / found at the time of data collection and is willing to be interviewed in traditional markets where the research is located. According [1], the required sample size is calculated using the Slovin formula as follows:

\subsection{Method of collecting data}

The data used in this research are primary data and secondary data. Primary data collection is done by direct interview method using an instrument in the form of a questionnaire that has been made previously. Data collected included data on the number of family dependents, education level, family income, purchase price of broiler chicken meat, tastes, age of the 
respondent, and substitute items (eggs). Secondary data was obtained from related institutions or institutions, such as the Binjai City Fisheries and Animal Husbandry Office, Binjai City Central Bureau of Statistics (BPS), North Sumatra Central Statistics Agency (BPS) and from the literature and other supporting sources.

\subsection{Data analysis method}

The analytical method carried out by multiple linear analysis methods derived with the least squares method was analyzed using SPSS 22.0 with seven independent variables, namely the number of dependents, education level, family income, broiler chicken prices, tastes, age of respondents and eggs as a substitution commodity and as a dependent variable, namely the demand for broiler chicken meat.

Multiple regression analysis is used by researchers, if the researcher intends to predict the state of the dependent variable (criterion) (criterion), if two or more independent variables are raised to decrease their value and multiple regression allows some additional variables to be introduced. So multiple regression analysis will be carried out if the number of independent variables is two or more than two [2].

This analysis uses the OLS (Ordinary Least Square) method or the least squares method with the SPSS 22.0 tool. The form of the model can be formulated as follows:

$$
Y=a+b_{1} X_{1}+b_{2} X_{2}+b_{3} X_{3}+b_{4} X_{4}+b_{5} X_{5}+b_{6} X_{6}+b_{7} X_{7}+\mu
$$

\subsection{Classic Assumption Test}

\subsubsection{Residual Normality Test}

This test is conducted to find out whether in a regression model, the residual value has a normal distribution or not. Residual is the difference between the $\mathrm{Y}$ variable and the $\mathrm{Y}$ variable that is specified. In the linear regression method, this is indicated by the magnitude of the random error (e) value that is normally distributed. A good regression model is normally distributed or near normal so that the data is feasible to be tested statistically.

\subsubsection{Multicollinearity Test}

Multicollinearity is a situation where between two or more independent variables in the regression model there is a perfect or near-perfect linear relationship. A good regression model requires no muticolinearity problems. To detect the presence or absence of multicollinearity in general by looking at the Tolerance and VIF values in the linear regression results. 


\subsubsection{Heteroscedasticity Test}

Heteroscedasticity is a condition in which the occurrence of residual variance inequalities in the regression model. A good regression model requires no heteroscedasticity problems.

\subsubsection{Coefficient of Determination}

$\mathrm{R}^{2}$ is used to measure how far the model's ability to explain variations in the dependent variable. The rest is explained by other variables not included in the model. With the SPSS 22.0 program the results of the coefficient of determination can be seen from the adjusted $\mathrm{R}$ square value [3].

\subsubsection{F Test}

The $\mathrm{F}$ test is used to test the effect of independent variables together on the dependent variable. The decision making is:

If F-count $\leq \mathrm{F}$-table, then $\mathrm{H} 0$ is accepted; $\mathrm{H} 1$ rejected If

F-count> F-table, then $\mathrm{H} 0$ is rejected; $\mathrm{H} 1$ accepted

\subsection{6. $T$ Test}

The $t$ test is used to test the effect of partially independent variables on the dependent variable.

According to [4], the use of hypothesis test criteria is:

If $\mathrm{t}$ count $>\mathrm{t}$ table or $-\mathrm{t}$ count $<-$ table; $\mathrm{H} 0$ is rejected and $\mathrm{H} 1$ is accepted

If $\mathrm{t}$ count $<\mathrm{t}$ table or $-\mathrm{t}$ count $>-\mathrm{t}$ table; $\mathrm{H} 0$ is accepted and $\mathrm{H} 1$ is rejected

(H0: no effect; H1: there is influence) 


\section{Results and Analysis}

\subsection{Descriptive Research Variables}

The description of the research variables provides an explanation of the research variables, namely the characteristics of respondents in the form of dependents, education level, income, and age of respondents, as well as the variable level of respondents' tastes, chicken prices and prices of substitute items (eggs). Based on the data collected, the source of information obtained is presented in the form of descriptive statistics in the form of maximum values, minimum values, mean and standard deviations. The following table describes the descriptive statistics of each research variable:

Table 1. Descriptive Statistics of Research Variables

\begin{tabular}{lrrrrr}
\hline \multirow{2}{*}{ Variabel } & \multicolumn{5}{c}{ Skor Empirik } \\
\cline { 2 - 6 } \multicolumn{1}{c}{ dependent } & \multicolumn{1}{c}{$\boldsymbol{N}$} & \multicolumn{1}{c}{ Min } & Max & Mean & \multicolumn{1}{c}{ Std. Dev } \\
\hline Family's & 100 & 7 & 3,92 & 1,253 \\
number (X1) & & & & & \\
Educational level (X2) & 100 & 1 & 3 & 2,45 & 0,592 \\
Family income (X3) & 100 & 750000 & 4500000 & 2462200,00 & 966308,795 \\
Price of broiler chicken & 100 & 30000 & 33000 & 31250,00 & 1282,162 \\
(X4) & & & & & \\
Taste (X5) & 100 & 3 & 4 & 3,44 & 0,499 \\
Age of respondent (X6) & 100 & 21 & 61 & 42,13 & 9,197 \\
Price of egg (X7) & 100 & 1100 & 1500 & 1242,50 & 96,236 \\
Demand (Y) & 100 & 2 & 9 & 5,39 & 1,922 \\
\hline
\end{tabular}

\subsection{Estimated Demand Function}

Based on the results of data analysis, the model of demand function for broiler chicken meat in Binjai City is as follows:

$$
\begin{aligned}
\mathrm{Y}= & 4,848+0,413 \mathrm{X}_{1}+0,167 \mathrm{X}_{2}+9,19.10^{-7} \mathrm{X}_{3}+0,000 \mathrm{X}_{4}+1,297 \mathrm{X}_{5}+0,006 \mathrm{X}_{6}-0,001 \mathrm{X}_{7}\left[R^{2}\right. \\
& =0,704]
\end{aligned}
$$

Where :

$\mathrm{Y}=$ Total consumption of chicken meat $(\mathrm{kg} /$ month)

$\mathrm{X} 1$ = Number of family dependents (soul)

$\mathrm{X} 2=$ Education level (year)

X3 = Family income (Rp / Month)

$\mathrm{X} 4$ = Price of broiler chicken (IDR / kg) 
$\mathrm{X} 5$ = Taste

$\mathrm{X} 6=$ Age of respondent (year)

$\mathrm{X} 7$ = Price of other commodities / eggs (Rp / Item)

$\mathrm{R}^{2}=$ coefficient of determination

\subsection{Testing Classical Assumptions}

\subsubsection{Residual Normality Test}

Table 2. Residual Normality Test Results

\begin{tabular}{clll}
\hline Variabel & $K S Z$ & Sig. & Conclusion \\
\hline $\begin{array}{c}\text { Unstandardized } \\
\text { Residual }\end{array}$ & 0,078 & 0,143 & Normal \\
\hline
\end{tabular}

Based on the table above it can be seen that the significance value is greater than 0.05 , which is equal to 0.143 , so it can be said that the residual data is normally distributed.

\subsubsection{Multicollinearity Test}

Table 3. Multicollinearity Test Results

\begin{tabular}{lccc}
\hline \multicolumn{1}{c}{ Variable } & Tolerance & VIF & Conclusion \\
\hline Family's dependent number & 0,611 & 1,638 & No multikolinearitas \\
(X1) & & & \\
Educational level (X2) & 0,908 & 1,101 & No multikolinearitas \\
Family income (X3) & 0,642 & 1,558 & No multikolinearitas \\
Price of broiler chicken (X4) & 0,949 & 1,053 & No multikolinearitas \\
Taste (X5) & 0,790 & 1,267 & No multikolinearitas \\
Age of respondent (X6) & 0,884 & 1,31 & No multikolinearitas \\
Price of egg (X7) & 0,859 & 1,164 & No multikolinearitas \\
\hline
\end{tabular}

The results of the analysis obtained by each independent variable namely tolerance value> 0.1 and VIF value $<10$, it can be stated that there is no multicollinearity between independent variables.

\subsubsection{Heteroscedasticity Test}

Table 4. Heteroscedasticity Test Results

\begin{tabular}{lcc}
\hline \multicolumn{1}{c}{ Variable } & Correlation Coefficient & Absolut Residual \\
\hline Family's dependent number & 0,162 & 0,106 \\
(X1) & & \\
Educational level (X2) & $-0,001$ & 0,995 \\
Family income (X3) & 0,155 & 0,124
\end{tabular}


Price of broiler chicken (X4)

Taste (X5)

Based on the table above the decision making results of heteroscedasticity test using the Spearman rho method, if the significance value between the independent variables with absolute residuals is more than 0.05 , there is no problem with heteroscedasticity, but if the significance value is less than 0.05 then heteroscedasticity problems occur.

\subsection{Model Testing}

\subsubsection{Coefficient of Determination $\left(R^{2}\right)$}

The coefficient of determination shows how much the percentage of contributions of the independent variables together on the dependent variable. Based on the results of the analysis obtained the adjusted $\mathrm{R}^{2}$ value of 0.704 . This shows that $70.4 \%$ of the demand for broiler chicken in Binjai City can be explained by the independent variables used in the model, namely the number of family dependents, family income, broiler meat prices, tastes, age of respondents, and prices of substitute goods egg. While the remaining $29.6 \%$ is explained by other variables outside the model.

\subsubsection{F Test}

Table 5. Results of Analysis of Variables that Influence the Demand of Broiler Chicken Meat in Binjai City

\begin{tabular}{llll}
\hline Modle & df & F count & Sig. \\
\hline Regression & 7 & 34,681 & 0,000 \\
Residue & 92 & & \\
\hline Total & 99 & & \\
\hline
\end{tabular}

Based on the F test analysis conducted it can be seen that the calculated F is obtained at 34,681 with a significance of $F=0,000<0,05$. This shows that the independent variables observed were family dependence, education level, family income, broiler meat prices, tastes, age of respondents, and egg prices together significantly affected the demand for broiler chicken meat in Binjai City.

\subsection{3. $t$ Test}

Table 6. Results of Test Analysis t Each Variable

$\begin{array}{cccc}\text { Variable } & \begin{array}{c}\text { Regression } \\ \text { Coefficient }\end{array} & \text { sig. }\end{array}$




\begin{tabular}{lccc}
\hline Family's dependent number & 0,413 & 3,844 & 0,000 \\
(X1) & & & \\
Educational level (X2) & 0,167 & 0,898 & 0,372 \\
Family income (X3) & $9,19.10^{-7}$ & 6,773 & 0,000 \\
Price of broiler chicken (X4) & 0,000 & $-2,534$ & 0,013 \\
Taste (X5) & 1,297 & 5,472 & 0,000 \\
Age of respondent (X6) & 0,006 & 0,487 & 0,628 \\
Price of egg (X7) & $-0,001$ & $-1,230$ & 0,222 \\
\hline
\end{tabular}

\section{Family's dependent number}

Based on the results of the analysis, it can be seen that the partial regression coefficient of the variable number of family dependents is 0.413 and the value of $t$ count is 3.844 . Significance value in the variable number of family dependents shows $0,000<0,05$, it can be said that the number of family dependents influence the demand for broiler chicken meat. The partial regression coefficient indicates that if the number of dependents increases by $1 \%$, then the demand for chicken meat will increase by $0.413 \%$

\section{Educational Level}

The results showed that the educational variables calculated were $0.898<1.987$ and could be stated partially that education did not affect the demand for broiler chicken in Binjai City.

\section{Family Income}

Based on the results of the analysis it can be seen that the partial regression coefficient of the income variable of the average family is equal to $9.19 .10-7$ and the value of $t$ count is 6.773 . The significance value of the income variable shows $0,000<0,05$, it can be said that the income variable influences the demand for broiler chicken meat. The partial regression coefficient shows that if income increases by $1 \%$, consumer demand for broiler chicken increases by $9.19 \times 10-7 \%$.

\section{Price of Broiler Chicken}

Significant value on the variable price of broiler chicken meat showed $0.013<0.05$, so it can be said that the variable price of broiler chicken meat itself affects the demand for broiler chicken meat. The partial regression coefficient shows that if the price of broiler chicken meat increases by $1 \%$, the consumer demand for broiler chicken meat increases by $0,000 \%$.

Taste

Significance value on consumer tastes variable shows $0,000<0,05$, so it can be said that variable consumer tastes influence the demand for broiler chicken meat. The partial regression 
coefficient shows that if consumer tastes increase by $1 \%$, the consumer demand for broiler chicken meat increases by $1.29 \%$.

\section{Age of Respondent}

Based on the results of the analysis it can be seen that the partial regression coefficient of the age variable of the respondent is equal to 0.006 and the calculated t value is 0.487 . The significance value of the respondent's age variable shows $0.628>0.05$, it can be said that the respondent's age variable did not influence the demand for broiler chicken meat. The partial regression coefficient shows that if the respondent's age increases by $1 \%$, the consumer demand for broiler chicken meat increases by $0.006 \%$.

\section{Price of Egg}

Based on the results of the analysis it can be seen that the partial regression coefficient of the egg price variable is equal to -0.001 and the value of $t$ count is -1.230 . The significance value of the egg price variable shows $0.222>0.05$, it can be said that the variable price of eggs does not affect the demand for broiler chicken meat. The partial regression coefficient shows that if the price of eggs increases by $1 \%$, the consumer demand for broiler chicken meat decreases by $0.001 \%$.

\section{Conclusions}

Based on regression analysis, it is known that the number of dependents, education level, family income, chicken prices, tastes, age of respondents, and egg prices have a positive effect on the demand for broiler chicken in Binjai City. Based on the partial analysis, it is known that the variables that have the most positive influence (increase) on the demand for broiler chicken are taste, then followed by the variable number of family dependents, price of chicken meat and family income. While the level of education, age of respondents and the price of eggs did not significantly affect the demand for broiler chicken in Binjai City.

\section{References}

[1] Churchill, G. A. 2005. Dasar- Dasar Riset Pemasaran. Edisi 4. Jilid I. Penerbit Erlangga. Jakarta

[2] Siswanto, H. B. 2005. Pengantar Manajemen. Bumi Aksara. Jakarta.

[3] Supriana, T. 2009. Pengantar Ekonometrika Aplikasi dalam Bidang Ekonomi Pertanian. Universitas Sumatera Utara. Medan

[4] Priyatno, D. 2016. Belajar Alat Analisis Data dan Cara Pengolahannya dengan SPSS.

Gava Media. Yogyakarta. 